\title{
PENILAIAN BAHAN AJAR MODUL MENGGAMBAR MODE MATERI PENYELESAIAN GAMBAR DESAIN BUSANA
}

\author{
Novia Safitri ${ }^{1}$, Muchamad \\ Noerharyono ${ }^{2}$, Melly \\ Prabawati ${ }^{3}$
}

\begin{abstract}
Afiliasi
${ }^{123}$ Pendidikan Tata Busana, Universitas Negeri Jakarta
\end{abstract}

\section{Contributor email :}

Jl. Rawamangun Muka Raya, RT. 11/RW.14, Rawamangun Email

noviasafitri498@gmail.com ${ }^{1}$, m.noerharyono@gmail.com ${ }^{2}$, mellyprabawati@unj.ac.id ${ }^{3}$

\section{ABSTRAK}

Penelitian ini bertujuan untuk mengetahui penilaian bahan ajar berbentuk modul dengan materi penyelesaian gambar desain busana berdasarkan aspek bahan ajar dan aspek karakteristik modul. Metode yang digunakan dalam penelitian ini adalah metode Pr-Eksperimental dengan desain OneShot Case Study. Penelitian ini menggunakan indikator penilaian aspek bahan ajar yaitu aspek materi, aspek penyajian, dan aspek kebahasaan, dan 5 karakteristik modul yaitu self instructional (pembelajaran diri), self contained (satu kesatuan), stand alone (berdiri sendiri), adaptive (menyesuaikan diri), dan user friendly (mudah digunakan). Hasil penelitian ini menyatakan bahwa secara keseluruhan penilaian modul menggambar mode materi penyelesaian gambar desain busana berdasarkan penilaian ahli materi dan ahli modul, modul ini berada pada kategori Sangat Baik (SB) dengan presentase rata-rata sebesar $92 \%$. Modul dapat dikatakan sangat baik karena modul menggambar mode materi penyelesaian gambar desain busana telah memenuhi kriteria berdasarkan ahli materi dan ahli modul. Penilaian dari ahli modul memperoleh nilai skor tertinggi dengan skor 92,32\% dengan hasil yang dapat dikatakan Sangat Baik (SB). Penilaian ahli materi berada pada urutan kedua dengan memperoleh nilai skor 91,75\% dengan hasil yang dapat dikatakan Sangat Baik (SB). Sedangkan aspek dari keseluruhan penilaian, aspek tertinggi yang mmepengaruhi hasil penilaian penelitian ini adalah aspek self contained (satu kesatuan) memperoleh nilai skor $100 \%$ dan aspek self instructional (pembelajaran sendiri) memperoleh skor terendah dengan nilai skor 89,81\%.

Kata Kunci: Penilaian, Modul, Menggambar Mode Penyelesaian Gambar Desain Busana

\section{ABSTRACT}

This research aims to determine the assessment of teaching materials in the form of modules with the completion of fashion design drawings based on aspects of teaching materials and aspects of module characteristics. The method used in this research is a quantitative pre-experimental method with a one shot case study design with quantitative descriptive data analysis techniques. This research uses a single variable, namely the module variable for drawing the material for the completion of fashion design drawings. The research indicators used are material aspects, presentation aspects, linguistic aspects, self-instructional, self-contained, stand-alone, adaptive, and user friendly. The results of this research indicate that the overall assessment of the fashion drawing module for the completion of fashion design drawings is based on the assessment of material experts and module experts, this module is in the Very Good (VG) category with an average percentage of $92 \%$. The module can categorized very good because the fashion drawing module for the completion of fashion design drawings has met the criteria based on material experts and module experts. The assessment from the module expert obtained the highest score with $92.32 \%$ with results that can be said to be very good (VG). The material expert's assessment is in second place by obtaining a score of $91.75 \%$ with results very good (VG). While the aspect of the overall 
assessment, the highest aspect that affects the results of the assessment of this research is the self contained aspect obtaining a score of $100 \%$ and the self-instructional aspect (self-learning) obtaining the lowest score with a score of $89.81 \%$.

Keywords: Assessment, Module, Drawing Fashion Design Drawing Completion Mode

\section{A. PENDAHULUAN}

Pendidikan merupakan suatu kegiatan yang terstruktur dan terencana untuk meningkatkan kemampuan keterampilan dan pengetahuan melalui proses pembelajaran sehingga peserta didik dapat mengembangkan potensi yang ada di dalam dirinya, seperti yang tertulis dalam Undang - Undang No.20 Tahun 2003 tentang SISTEM PENDIDIKAN NASIONAL, Bab I Pasal 1 menyatakan bahwa "Pendidikan adalah usaha sadar dan terencana untuk mewujudkan suasana belajar dan proses pembelajaran agar peserta didik secara aktif mengembangkan potensi dirinya untuk memiliki spiritual keagamaan, pengendalian diri, kepribadian, kecerdasan, akhlak mulia serta ketrampilan yang diperlukan dirinya, masyarakat, bangsa dan negara" (Junaedi, 2019).

Proses pembelajaran merupakan suatu kegiatan utama dalam sekolah yang terencana untuk megupayakan belajar siswa dengan menggunakan sumber-sumber untuk belajar siswa sehingga terjadi dorongan untuk mengembangkan kemampuan berpikir siswa dalam menerima dan mengingat informasi secara efektif. Dalam menciptakan pembelajaran yang berkualitas yaitu dengan melakukan kegiatan pembelajaran yang melibatkan seluruh komponen yaitu guru, siswa, interaksi keduanya, unsur - unsur pembelajaran, sarana prasarana yang menunjang, dan lingkungan yang kondusif dan mendukung berlangsungnya kegiatan belajar mengajar sehingga guru dapat meletakkan tempatnya dengan tepat untuk kebutuhan belajar siswa dengan efektif dan memudahkan siswa belajar dengan menyenangkan sehingga dapat mencapai tujuan pembelajaran sesuai dengan yang diharapkan.

Mata kuliah Menggambar Mode adalah salah satu mata kuliah yang membahas tentang cara menggambar manusia, meliputi proporsi dan anatomi mode, gerak dan gaya, serta menggambar ilustrasi busana dan bagian-bagiannya dengan menampilkan tekstur dan teknik pewarnaan tertentu, dimana pada setiap mata kuliah memiliki Capaian Pembelajaran Mata Kuliah (CPMK). Adapun tujuan dari mata kuliah ini adalah agar mahasiswa memiliki pengetahuan dan keterampilan tentang cara menggambar manusia meliputi proporsi dan anatomi mode, gerak dan gaya, serta menggambar ilustrasi busana dan bagian-bagiannya dengan menampilkan tekstur dan teknik pewarnaan tertentu.

Penyelesaian gambar desain busana merupakan pewarnaan pada sketsa desain busana yang telah dibuat dengan terdapat 2 teknik dalam penyelesaian gambar desain busana yaitu pewarnaan dengan teknik kering dan pewarnaan dengan teknik basah. Teknik pewarnaan kering merupakan teknik pewarnaan yang tidak memilki kesan basah atau tidak menggunakan air dalam pewarnaannya, sedangkan teknik pewarnaan basah adalah teknik pewarnaan yang memiliki kesan basah dan menggunakan air dalam pewarnaannya.

Berdasarkan hasil dari wawancara yang telah dilakukan oleh peneliti dengan Dosen pengampu Menggambar Mode dan beberapa mahasiswa Pendidikan Tata Busana yang telah mengambil mata kuliah Menggambar Mode, proses pembelajaran di dalam kelas mata kuliah Menggambar Mode telah di sampaikan dengan maksimal oleh dosen pengampu. 
Penyampaian materi dilakukan dengan video tutorial dan power point mulai dari pembuatan proporsi tubuh hingga penyelesaian gambar desain busana tetapi hanya secara gambaran umum. Namun, masih terdapat beberapa mahasiswa yang mengalami kesulitan dalam penyelesaian gambar desain busana dengan teknik pewarnaan kering dan teknik pewarnaan basah, terutama dalam menerapkan efek gelap terang dan mewarnai tekstur bahan pada desain busana yang dibuat. Salah satu yang menjadi faktor utama adalah karena pada mata kuliah Menggambar Mode belum memiliki bahan ajar berupa buku paket atau modul yang lebih fokus dalam materi penyelesaian gambar desain busana yang dapat dijadikan sebagai referensi dalam kegiatan pembelajaran didalam kelas. Diharapkan dengan adanya bahan ajar berupa modul yang dapat menjadi sarana media pembelajaran untuk bisa belajar secara mandiri, sehingga mahasiswa dapat memberikan hasil yang lebih maksimal pada proses pembelajaran mata kuliah Menggambar Mode.

Bahan ajar merupakan salah satu unsur terpenting yang dapat digunakan oleh pendidik untuk memudahkan pendidik dalam menyampaikan materi pada setiap mata kuliah, bahan ajar juga sangat memudahkan mahasiswa belajar baik di dalam kelas maupun dirumah secara mandiri karena dapat dipelajari secara berulang-ulang.

"Modul merupakan suatu kesatuan bahan ajar yang disajikan secara sistematis dan menarik sehingga bahan ajar yang disusun di dalam modul dapat dipelajari siswa secara mandiri dengan bantuan yang terbatas dari pendidik atau orang lain berdasarkan buku Departemen Pendidikan Nasional yang berjudul "Teknik Bahan dengan Bahan Ajar Modul" " (Depdiknas, 2008)Modul pembelajaran dapat dikemas dalam suatu bahan ajar yang dibuat menarik dan dicetak, modul sangat membantu pendidik dalam mengajar dan memudahkan mahasiswa dalam memahami, mengikuti, dan mengulang materi pelajaran mata kuliah secara mandiri sehingga meningkatkan hasil belajar. Dengan menggunakan modul cetak, mahasiswa diharapkan mampu mencapai kompetensi belajar karena sudah dirancang sedemikian rupa dan dapat belajar kapan pun dan dimana pun dengan tuntas menggunakan sumber yang tepat.

Penilaian pada penelitian ini berguna untuk mengetahui nilai produk modul cetak ini berdasarkan beberapa aspek penilaian yaitu aspek bahan ajar yang baik dan aspek karakteristik modul yang baik berdasarkan aspek bahan ajar yang baik menurut Abidin (2014) dalam Muliawani \& Firman (2019) meliputi aspek materi, aspek penyajian dan aspek kebahasaan dan karakteristik modul yang baik menurut Depdiknas (2008) yaitu Self Instructional, Self Contained, Stand Alone, Adaptive, dan User Friendly.

Berdasarkan latar belakang permasalahan yang telah dipaparkan, membuat peneliti tertarik untuk membuat bahan ajar berupa modul yang dinilai sesuai dengan aspek bahan ajar dan aspek karakteristik modul yang baik dengan mengambil judul "Penilaian Bahan Ajar Modul Menggambar Mode Materi Penyelesaian Gambar Desain Busana". Dengan dilakukannya penilaian pada bahan ajar modul menggambar mode materi penyelesaian gambar desain busana ini, peneliti berharap bahan ajar modul ini akan dapat membantu mahasiswa untuk memperoleh sumber bacaan atau referensi dalam mempelajari materi penyelesaian gambar desain busana secara kering dan basah, karena modul ini akan menyajikan materi dan langkah-langkah beserta gambar dalam penyelesaian gambar desain busana yang terdiri dari pewarnaan dengan teknik kering dan pewarnaan dengan teknik basah. 


\section{B. METODE PENELITIAN}

Tujuan operasional pada penelitian ini yang ingin dicapai adalah untuk mengetahui penilaian bahan ajar berbentuk modul cetak dengan materi Penyelesaian Gambar Desaian Busana pada mata kuliah Menggambar Mode. Penilaian modul ini dengan indikator 3 aspek bahan ajar yaitu aspek materi, aspek penyajian, dan aspek kebahasaan. Dan 5 aspek karakteristik modul yang baik yaitu Self Instructional, Self Contained, Stannd Alone, Adaptive, dan User Friendly. Dilaksanakan di Program Studi Pendidikan Tata Busana Universitas Negeri Jakarta. Waktu pelaksanaan dari bulan Agustus 2021 sampai Januari 2022.

Metode yang digunakan dalam penelitian ini adalah kuantitatif model preesperimental design yang digunakan adalah One-shot Case Study.

Tabel 2.1 Pola Desain One-shot Case Study

\section{$\mathbf{X} \longrightarrow \mathbf{O}$}

Keterangan gambar :

$\mathrm{X}=$ Treatment produk/perlakuan

$\mathrm{O}=$ Observasi proses dan hasil

Tabel 2.2 Desain One-shot Case Study

\begin{tabular}{|l|l|}
\hline \multicolumn{1}{|c|}{$\mathbf{X}$} & \multicolumn{1}{c|}{$\mathbf{O}$} \\
\hline Bahan ajar & Penilaian \\
modul & menggunakan \\
menggambar & teori aspek bahan \\
mode materi & ajar dan aspek \\
penyelesaian & karakteristik \\
gambar desain & modul \\
busana & \\
\hline
\end{tabular}

Pada penelitian ini hanya terdapat satu variable penelitian (variable tunggal), yaitu penilaian bahan ajar modul menggambar mode materi penyelesaian gambar desain busana. Subjek penelitian ini menggunakan 4 subjek penelitian sebagai informan, yaitu 2 panelis ahli berdasarkan aspek materi dan 2 panelis ahli berdasarkan aspek modul. Objek penelitian yaitu bahan ajar berupa modul. Instrumen yang digunakan pada penelitian ini adalah angket/ kuesioner tertutup-terbuka (campuran). Dan menggunakan skala rating scale.

Tabel 2.3 Interval Jawaban Pada Rating Scale

\begin{tabular}{|c|c|}
\hline $\begin{array}{c}\text { Interval } \\
\text { Jawaban }\end{array}$ & Alternatif Jawaban \\
\hline 1 & Sangat Tidak Baik \\
\hline 2 & Tidak Baik \\
\hline 3 & Baik \\
\hline 4 & Sangat Baik \\
\hline
\end{tabular}

Uji validitas intsrumen yang digunakan dalam penelitian ini yaitu uji validitas konstruk. Dalam penelitian ini teknik pengumpulan data yang digunakan adalah kombinasi angket tertutup-terbuka (campuran) dengan langkah-langkah sebagai berikut:

1. Merancang pertanyaan penelitian sesuai dengan kisi-kisi instrumen.

32 |Practice of Fashion and Textile Education Journal; Vol 2, No 1. 
2. Memilih narasumber ahli untuk melakukan uji validitas instrumen.

3. Memilih panelis ahli materi dan ahli modul untuk penilaian modul cetak yang telah dibuat berdasarkan instrumen.

4. Data yang telah terkumpul, kemudian di tabulasi secara kuantitatif deskriptif. Hasil tabulasi data akan di deskripsikan dan dijadikan sebagai hasil analisis yang kemudian data akan di interpretasi yaitu tentang bahan ajar berupa modul cetak.

Teknik analisis data yang digunakan dalam penelitian ini yaitu teknik analisis kuantitatif dengan menggunakan pendekatan statistik deskriptif

\section{LANDASAN TEORI}

a) Penilaian

1. Definisi Penilaian

Menurut Brown (2004:4) menyatakan bahwa penilaian adalah metode yang digunakan untuk mengukur kemampuan, pengetahuan, atau performa seseorang (Abidin, 2014:77). Lebih lanjut penilaian dalam pendidikan adalah keputusan - keputusan yang diambil secara umum dalam hal perencanaan, pengelolaaan, proses, dan tindak lanjut penddikan baik menyangkut perorangan, kelompok, atau kelembagaan (Arif \& Armai, 2020).

Berdasarkan definisi penilaian menurut ahli diatas, maka dapat disimpulkan bahwa penilaian merupakan suatu proses kegiatan untuk mengelola dan mengumpulkan informasi untuk mengetahui dan mengambil keputusan hasil dari pengukuran yang digunakan.

2. Aspek Bahan Ajar

Penjelasan aspek bahan ajar menurut Abidin (2014) bahwa bahan ajar yang dikembangkan harus memiliki pedoman penilaian bahan ajar yaitu sebagai berikut :
a. Aspek materi
b. Aspek penyajian
c. Aspek kebahasaan

3. Karateristik Modul

Menurut Depdiknas (2008 : 3-5) modul dapat dikatakan baik dan menarik apabila terdapatkarakteristik dalam modul antara lain :

a. Self Instructional, artinya modul dapat membuat peserta belajar belajar secara mandiri dan tidak bergantung pada pihak lain.

b. Self Contained, artinya seluruh materi pembelajaran terdapat dalam satu modul secara utuh yang terdiri dari satu unit kompetensi maupun subkompetensi yang akan dipelajari, agar peserta belajar dapat mempelajari materi pembelajaran secara tuntas.

c. Stand Alone atau berdiri sendiri, artinya modul yang dikembangkan tidak menggunakan media lain secara bersamaan untuk mempelajari dan atau mengerjakan tugas dari modul tersebut.

d. Adaptive, artinya modul yang dikembangkan tetap up to date menyesuaikan dengan perkembangan ilmu pengetahuan dan teknologi serta fleksibel untuk digunakan. Isi materi pembelajaran modul dapat digunakan hingga kurun waktu tertentu.

e. User Friendly, artinya modul bersahabat dengan penggunanya atau bersifat membantu dan memudahkan pemakai dalam merespon, mengakses sesuai dengan keinginan dan menggunakan bahasa yang sederhana dan efektif serta penggunaan istilah yang umum digunakan. 


\section{b) Bahan Ajar}

1. Definisi Bahan Ajar

Bahan ajar menurut Widodo (2008:40) merupakan sarana atau alat pembelajaran yang dibuat secara sistematis dan menarik terdiri dari materi pembelajaran metode, batasan - batasan, dan evaluasi untuk tercapainya kompetensi atau subkompetensi sesuai yang diharapkan (Utami, 2020).

Sedangkan menurut Depdiknas (2008:6-7) bahan ajar adalah bagian dari sumber belajar, bahan ajar merupakan bentuk bahan baik secara tertulis maupun secara tidak tertulis yang disusun secara sistematis digunakan untuk membantu guru dalam melaksanakan kegiatan pembelajaran sehingga tercipta suasana lingkungan yang membuat peserta didik dapat belajar.

\section{Fungsi Bahan Ajar}

Terdapat 3 fungsi utama bahan ajar berdasarkan penyelenggaraan proses belajar dan pembelajaran (Salaka, 2020).

a. Bahan ajar merupakan pedoman bagi guru untuk mengarahkan aktivitas dalam proses belajar dan pembelajaran sesuai kompetensi yang akan diajarkan kepada siswa.

b. Bahan ajar merupakan arahan aktivitas kegiatan belajar sebagai pedoman untuk peserta didik yang harus dipelajari.

c. Bahan ajar merupakan alat evaluasi pencapaian hasil pembelajaran peserta didik yang sesuai dengan indicator dan kompetensi yang ingin dicapai oleh guru kepada peserta didik sesuai dengan perumusan dalam silabus mata pelajaran.

Berdasarkan pendapat para ahli yang telah dipaparkan fungsi bahan ajar adalah sebagai sarana atau alat evaluasi yang telah dirancang untuk mengarahkan guru dan dipelajari siswa sehingga tercapainya kompetensi pembelajaran yang diharapkan.

3. Manfaat Bahan ajar

Menurut Depdiknas (2008 : 9) terdapat beberapa manfaat yang didapatkan oleh guru jika mengembangkan bahan ajar yaitu :

a. memperoleh bahan ajar yang sesuai dengan kurikulum untuk siswa belajar.

b. tidak bergantung dengan buku teks yang sulit didapatkan

c. memperbanyak referensi yang digunakan pada bahan ajar

d. menambah pengalaman guru dalam menulis

e. tercipatanya komunikasi pembelajaran yang interaktif dan efektif antara guru dan sisiwa

f. guru dapat menerbitkan bahan ajar yang dibuat menjadi buku yang diterbitkan Sedangkan manfaat bagi siswa yaitu :

a. kegiatan pembelajaran menjadi menarik

b. memotivasi siswa untuk belajar mandiri

c. siswa mendapatkan kemudahan untuk mempelajarikompetensi yang harus dikuasai

4. Jenis - jenis Bahan Ajar

Di dalam Modul 1 Hakikat Bahan ajar drh. Ida Malati Sadjati, M.Ed. menjelaskan bahan ajar dapat dikelompokkan menjadi 2 jenis bahan ajar yaitu sebagai berikut :

a. bahan ajar cetak 
Bahan ajar cetak adalah sejumlah bahan yang disiapkan dalam kertas, yang dapat berfungsi untuk keperluan pembelajaran atau penyampaian informasi (Kemp dan Dayton, 1985).

b. bahan ajar noncetak

Bahan ajar noncetak yaitu bahan ajar yang tida di cetak. Jenis bahan ajar noncetak adalah sebagai berikut :

1. Bahan ajar display

2. Overhead Transparencies (OHT)

3. Audio

4. Video

5. Bahan ajar berbasiskan computer

c) Modul

1. Definisi Modul

Modul merupakan bahan ajar yang dikemas secara utuh dan sistematis yang berisikan tujuan pembelajaran, materi atau substansi, serta evaluasi untuk memudahkan peserta didik dalam belajar sehingga peserta didik mampu menguasai tujuan belajar yang spesifik sesuai yang diharapkan. Lebih lanjut menurut Purwanto dkk (2007 : 9) menjelaskan bahwa modul merupakan bahan ajar yang disusun dalam bentuk satuan pembelajaran terkecil secara sistematis sesuai dengan kurikulum dan dapat dipelajari secara mandiri (Izzati \& Fatikhah, 2015).

Definisi modul menurut Depdiknas (2008 : 3) modul adalah bahan ajar cetak atau disebut bahan instruksional mandiri yang digunakan untuk pesertadidik mempelajari materi isi modul secara mandiri karena sudah dilengkapi petunjuk dalam penggunaan modul yang berisi materi, metode, batasan, dan evaluasi yang dirancang secara sistematis dan menarik oleh karena itu peserta didik mampu mempelajari modul secara langsung tanpa bantuan dari tenaga pengajar dan mampu mencapai kompetensi yang diharapkan.

2. Tujuan Modul

Tujuan modul menurut Depdiknas (2008 : 5-6) penulisan modul memiliki tujuan sebagai berikut

a. Memperjelas dan mempermudah penyajian pesan agar tidak terlalu bersifat verbal.

b. Mengatasi keterbatasan waktu, ruang, dan daya indera, baik peserta belajar maupun guru/ instruktur.

c. Dapat digunakan secara tepat dan bervariasi, seperti untuk meningkatkan motivasi dan gairah belajar mengembangkan kemampuan dalam berin- teraksi langsung dengan lingkungan dan sumber belajar lainnya yang memungkinkan siswa atau pebelajar belajar mandiri sesuai kemampuan dan minatnya.

d. Memungkinkan siswa atau pebelajar dapat mengukur atau mengevaluasi sendiri hasil belajarnya.

3. Manfaat Modul

Menurut Depdiknas (2008 : 7-8) Pembelajaran menggunakan modul bermanfaat untuk hal-hal sebagai berikut:

a. Meningkatkan efektivitas pembelajaran tanpa harus melalui tatap muka secara teratur karena kondisi geografis, sosial ekonomi, dan situasi masyarakat;

b. Menentukan dan menetapkan waktu belajar yang lebih sesuai dengan kebutuhan dan perkembangan belajar peserta didik;

c. Secara tegas mengetahui pencapaian kompetensi peserta didik secara bertahap melalui kriteria yang telah ditetapkan dalam modul; 
d. Mengetahui kelemahan atau kompetensi yang belum dicapai peserta didik berdasarkan kriteria yang ditetapkan dalam modul sehingga tutor dapat memutuskan dan membantu peserta didik untuk memperbaiki belajarnya serta melakukan remediasi.

\section{Kelebihan Modul}

Kelebihan pembelajaran dengan modul yaitu dapat memberikan umpan balik sehingga peserta didik dapat mengetahui kekurang mereka dan melakukan perbaikan, dengan adanya tujuan pembelajaran yang jelas membuat peserta didik lebih belajar secara terarah untuk mencapai tujuan pembelajaran, modul yang menarik, mudah dipelajari dan memenuhi kebutuhan belajar membuat peserta didik lebih termotivasi untuk belajar, modul bersifat fleksibel sehingga peserta didik mampu menyesuaikan kemampuannya, kerjasama dapat terjalin, siswa dapat mengetahui sendiri kelemahannya melalui evaluasi (Harta et al., 2014)

d) Penyelesaian Gambar Desain Busana

1. Definisi Penyelesaian Gambar Desain Busana

Menurut Ernawati (2008 : 241) pewarnaan atau penyelesaian gambar busana merupakan penyelesaian gambar desain yang dilakukan dengan penyelesaian menggunakan pensil biasa (2B atau 3B), penyelesaian menggunakan pensil warna, dan penyelesaian dengan cat air. pewarnaan atau penyelesaian gambar desain busana yang ditinjau dari alat dan bahan dikelompokan dalam penyelesaian secara kering (tanpa air) dan penyelesaian secara basah (dengan campuran air)

2. Faktor-faktor Yang Perlu Diperhatikan Dalam Penyelesaian Gambar Desain Busana Menurut Bestari (2011:50) dalam pewarnaan gambar desain busana terdapat faktor - faktor yang perlu diperhatikan yaitu :
a. Tekstur kain
b. Motif kain
c. Lekuk tubuh
d. Jatuhnya busana
e. Cahaya

3. Macam-macam Penyelesaian Gambar Desain Busana

a. Penyelesaian Gambar Desain Busana Dengan Teknik Kering

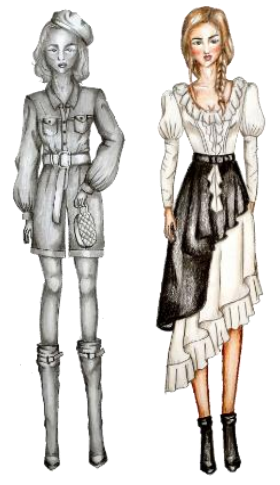

Gambar 3.1 Penyelesian Gambar Desain Busana Secara Kering

Menurut Bestari (2011:50) penyelesaian gambar desain busana dengan teknik kering adalah teknik pewarnaan sketsa yang tidak menggunakan air dengan menggunakan pensil, pensil warna, pastel, crayon, konte, spidol, marker dan lain sebagainya sesuai dengan keinginan. 


\section{b. Penyelesaian Gambar Desain Busana Dengan Teknik Basah}

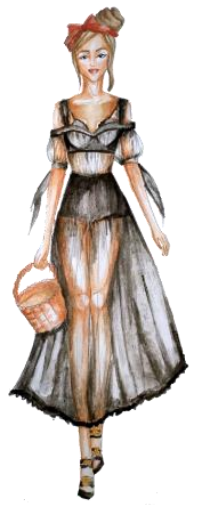

Gambar 3.2 Penyelesian Gambar Desain Busana Secara Basah

Penyelesaian gambar desain busana dengan teknik basah adalah teknik pewarnaan sketsa busana yang menggunakan campuran air dalam pewarnaannya (Uswatun Hasanah, dkk 2014 : 30). Penyelesaian gambar desain busana dengan teknik pewarnaan basah biasanya menggunakan cat air dan cat akrilik dan teknik ini lebih sulit dibandingkan dengan teknik pewarnaan kering.

e) Kerangka Berfikir

Menggambar mode merupakan salah satu mata kuliah praktik pada program studi Pendidikan Tata Busana. Pada sub capaian pembelajaran mata kuliah menggambar mode terdapat praktik penyelesaian gambar desain busana dengan teknik pewarnaan kering dan basah. berdasarkan hasil wawancara yang telah dilakukan peneliti kepada dosen pengampu dan mahasiswa Pendidikan Tata Busana yang telah mengambil mata kuliah tersebut, masih terdapat beberapa mahasiswa yang belum mencapai hasil yang maksimal dalam menyajikan tugas dalam penyelesaian gambar desain busana terutama untuk menciptakan efek gelap terang menggunakan cat air atau penyelesaian secara basah, dan tidak adanya referensi bahan ajar berupa modul sebagai pembelajaran untuk mahasiswa agar dapat mempelajari materi secara mandiri sebagai pegangan mahasiswa untuk belajar. Karena buku tentang penyelesaian gambar desain busana yang menyajikan langkah-langkah dalam pewarnaan penyelesaian gambar desain busana sangat sulit dicari sehingga menyulitkan mahasiswa untuk mendapatkan informasi. Dengan demikian perlu adanya bahan ajar berupa modul sebagai solusi untuk membantu mahasiswa dalam menjelaskan materi berupa Penyelesaian Gambar Desain Busana yang menjelaskan secara lengkap dan langkah kerja yang sistematis dalam penyelesaian gambar desain busana yang sesuai dengan Capaian Pembelajaran Mata Kuliah Menggambar Mode di Universitas Negeri Jakarta. Berdasarkan uraian yang telah di paparkan diatas, maka untuk mengatasi masalah tersebut, peneliti tertarik untuk membuat referensi bahan ajar berupa modul yang disusun secara sistematis dan dikemas dengan menarik dengan menyajikan ilustrasi atau gambar yang menarik untuk dapat mempermudah mahasiswa dalam mempelajari materi tersebut secara mandiri, sehingga mampu meningkatkan pemahaman mahasiswa dalam materi Penyelesaian Gambar Desain Busana sesuai dengan capaian pembelajaran mata kuliah yang diharapkan. Modul Menggambar Mode pada Materi Penyelesaian Gambar Desain Busana ini dinilai berdasarkan dua aspek, yaitu aspek bahan ajar dan aspek karakteristik modul yang baik yang akan dinilai oleh 4 panelis ahli di bidangnya.

Aspek materi dinilai berdasarkan aspek bahan ajar yaitu : 1) Aspek Materi, 2) Aspek Penyajian, 3) Aspek Kebahasaan. Sedangkan Aspek modul dinilai berdasarkan aspek 
karakteristik modul yang baik meliputi : 1) Self Intructional, 2) Self Contained, 3) Stand Alone, 4) Adaptif, 5) User Friendly.

\section{HASIL DAN PEMBAHASAN}

\section{- a. HASIL}

Pada pembuatan modul ini, proses pertama yang dilakukan untuk membuat bahan ajar berupa modul yaitu mengumpulkan berbagai informasi dan materi-materi yang sesuai dengan konsep Menggambar Mode Penyelesaian Gambar Desain Busana dari berbagai sumber yang ada. Kemudian, materi yang telah terkumpul disusun dan dirancang, diindentifikasi berdasarkan Rencana Pembelajaran Semester (RPS) mata kuliah menggambar mode. Identifikasi ini mencakup tujuan pembelajaran, Capaian Mata Kuliah (CPMK), Sub CPMK dan pokok materi. Sehingga didapatkan garis besar materi yang akan disusun menjadi pokok bahasan dalam modul ini yaitu kegiatan belajar 1 pengetahuan penyelesaian gambar desain busana, kegiatan belajar 2 penyelesaian gambar desain busana secara kering, dan kegiatan belajar 3 penyelesaian gambar desain busana secara basah. Penyusunan modul ini menggunakan berbagai program yaitu Microsoft Office (Microsoft Word) untuk penyusunan teks materi, platform desain grafis online Canva untuk background dan layout modul. Pembuatan gambar-gambar penyelesaian gambar desain busana secara kering dan basah yang pada setiap langkah-langkah dalam pembuatan gambar difoto kemudian gambar di scan menggunakan aplikasi camscanner dan menghapus background pada gambar menggunakan aplikasi background eraser. Modul ini dikemas dalam bentuk cetak dengan spesifikasi ukuran A4 (panjang $29 \mathrm{~cm}$ dan lebar $21 \mathrm{~cm}$ ), ukuran huruf pada isi modul 12 dengan jenis huruf tipografi Glacial Indifference. Sampul pada modul menggunakan kertas Art Paper yang kemudian dikemas secara keseluruhan dengan sampul Glossy Cover dengan laminating Glossy, sedangkan pada isi modul menggunakan jenis kertas HVS.
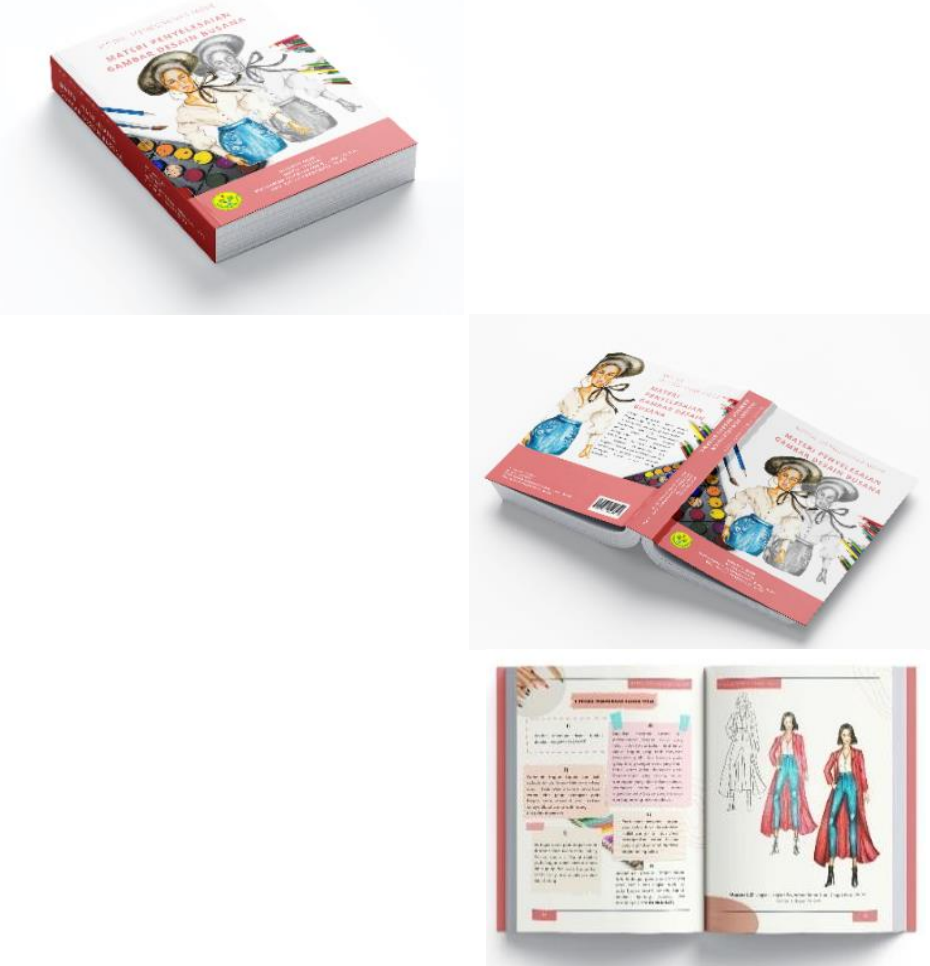

Gambar 4.1 Tampilan Modul

38 |Practice of Fashion and Textile Education Journal; Vol 2, No 1. 
Bahan ajar modul berbasis cetak yang dibuat oleh peneliti dinilai berdasarkan penilaian aspek bahan ajar (Abidin, 2014) yaitu aspek materi, aspek penyajian, dan aspek kebahasaan. Adapun penilaian oleh ahli materi adalah sebagai berikut:

Tabel 4.1 Tabel Skor Penilaian Modul Berdasarkan Ahli Materi

\begin{tabular}{|l|c|c|}
\hline \multicolumn{1}{|c|}{ Aspek } & $\begin{array}{c}\text { Jumlah } \\
\text { Pernyataan }\end{array}$ & $\begin{array}{c}\text { Jumlah } \\
\text { Skor }\end{array}$ \\
\hline Aspek Materi & 20 & 146 \\
\hline $\begin{array}{l}\text { Aspek } \\
\text { Penyajian }\end{array}$ & 17 & 126 \\
\hline $\begin{array}{l}\text { Aspek } \\
\text { Kebahasaan }\end{array}$ & 13 & 95 \\
\hline \multicolumn{1}{|c|}{ Jumlah } & $\mathbf{5 0}$ & $\mathbf{3 6 7}$ \\
\hline
\end{tabular}

\section{Jumlah Skor Kriteria}

Kategori $=$ Bobot Nilai $\times$ Jumlah Panelis $\times$ Jumlah Pernyataan

Sangat Baik $(S B)=4 \times 2 \times 50=400$

Baik (B) $\quad=3 \times 2 \times 50=300$

Tidak Baik $(\mathrm{TB})=2 \times 2 \times 50=200$

Sangat Tidak Baik (STB) $=1 \times 2 \times 50=100$

Secara keseluruhan, hasil angket pada ahli materi mendapatkan nilai yang sangat baik. Hal ini berkaitan dengan penilaian modul menurut ahli materi dapat dikatakan sangat baik sesuai dengan karakteristik yang diperlukan bahan ajar modul yang harmonis, bermutu, dan bermartabat yaitu dengan memperhatikan aspek materi, aspek penyajian, dan aspek kebahasaan (Abidin: 2014).

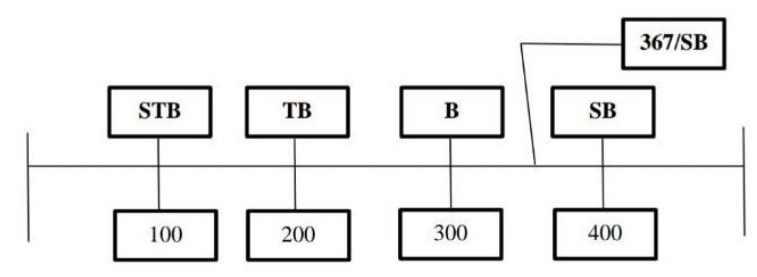

$\begin{aligned} \text { Persentase } & =367 / 400 \times 100 \% \\ & =91,75 \%\end{aligned}$

Hasil keseluruhan dari ahli materi dapat dilihat dari grafik dibawah ini:

Grafik 4. 1 Hasil Persentase Penilaian Ahli Materi

\section{Penilaian Ahli Materi}

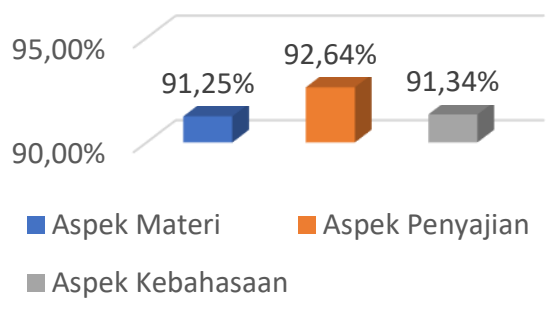


Bahan ajar modul berbasis cetak yang dibuat oleh peneliti dinilai juga berdasarkan penilaian aspek karakteristik modul (Depdiknas, 2008) yaitu self instructional (pembelajaran diri), self contained (satu kesatuan), stand alone (berdiri sendiri), adaptive (menyesuaikan diri), dan user friendly (mudah digunakan). Adapun penilaian oleh ahli modul adalah sebagai berikut:

Tabel 4.2 Tabel Skor Penilaian Modul Berdasarkan Ahli Modul

\begin{tabular}{|l|c|c|}
\hline \multicolumn{1}{|c|}{ Aspek } & $\begin{array}{c}\text { Jumlah } \\
\text { Pernyataan }\end{array}$ & $\begin{array}{c}\text { Jumlah } \\
\text { Skor }\end{array}$ \\
\hline $\begin{array}{l}\text { Aspek Self Instructional } \\
\text { (Pembelajaran Sendiri) }\end{array}$ & 27 & 194 \\
\hline $\begin{array}{l}\text { Aspek Self Contained (Satu } \\
\text { Kesatuan) }\end{array}$ & 6 & 48 \\
\hline $\begin{array}{l}\text { Aspek Stand Alone (Berdiri } \\
\text { Sendiri) }\end{array}$ & 3 & 23 \\
\hline $\begin{array}{l}\text { Aspek Adaptive } \\
\text { (Menyesuaikan Diri) }\end{array}$ & 4 & 29 \\
\hline $\begin{array}{l}\text { Aspek User Friendly (Mudah } \\
\text { Digunakan) }\end{array}$ & 4 & 31 \\
\hline \multicolumn{1}{|c|}{ Jumlah } & 44 & 325 \\
\hline
\end{tabular}

\section{Jumlah Skor Kriteria}

Kategori $=$ Bobot Nilai $\mathrm{x}$ Jumlah Panelis $\mathrm{x}$ Jumlah Pernyataan

Sangat Baik $(S B)=4 \times 2 \times 44=352$

Baik (B) $\quad=3 \times 2 \times 44=264$

Tidak Baik (TB) $=2 \times 2 \times 44=176$

Sangat Tidak Baik (STB) $=1 \times 2 \times 44=88$

Secara keseluruhan, hasil angket pada ahli modul mendapatkan nilai yang sangat baik. Hal ini berkaitan dengan penilaian modul menurut ahli modul dapat dikatakan sangat baik sesuai dengan karakteristik modul yang diperlukan pada modul yang baik dan menarik yaitu dengan memperhatikan aspek self instructional, self contained, stand alone, adaptive, dan user friendly (Depdiknas: 2008).

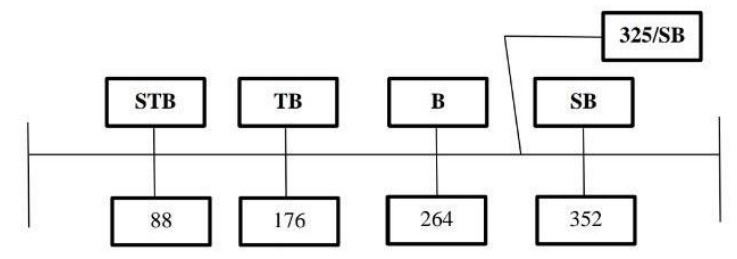

$$
\begin{aligned}
\text { Persentase } & =325 / 352 \times 100 \% \\
& =92,32 \%
\end{aligned}
$$

Hasil keseluruhan dari ahli modul dapat dilihat dari grafik dibawah ini: 
Grafik 4. 2 Hasil Persentase Penilaian Ahli Modul

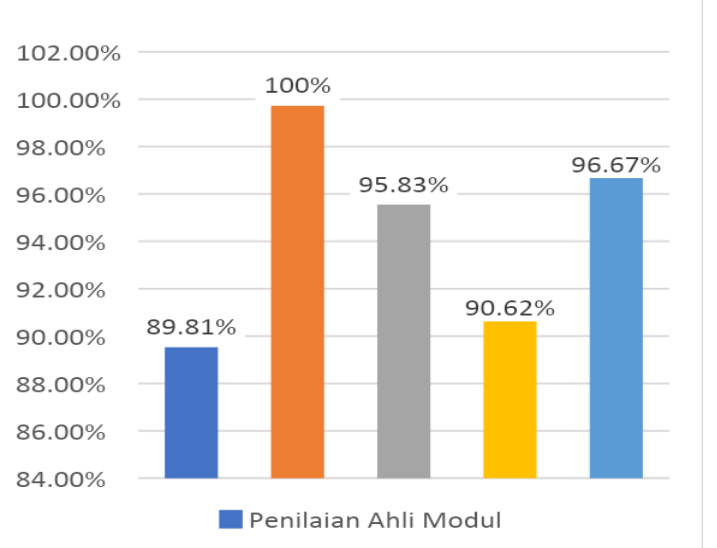

Setelah melalui proses penilaian melalui angket pada setiap aspek ahli materi dan ahli modul, maka didapatkan hasil akhir penilaian melalui peresntase penilaian ahli materi dan ahli modul pada bahan ajar modul menggambar mode materi penyelesaian gambar desain busana sebagai berikut:

Tabel 4.3 Tabel Skor Penilaian Modul Berdasarkan Ahli Materi dan Ahli Modul

\begin{tabular}{|c|c|c|}
\hline Panelis & $\begin{array}{c}\text { Jumlah } \\
\text { Pernyataan }\end{array}$ & $\begin{array}{c}\text { Jumlah } \\
\text { Skor }\end{array}$ \\
\hline Ahli Materi & 50 & 367 \\
\hline Ahli Modul & 44 & 325 \\
\hline Jumlah & $\mathbf{9 4}$ & $\mathbf{6 9 2}$ \\
\hline
\end{tabular}

\section{Jumlah Skor Kriteria}

Kategori $=$ Bobot Nilai $x$ Jumlah Panelis $x$ Jumlah Pernyataan

Sangat Baik (SB) $=4 \times 2 \times 94=752$

Baik (B) $\quad=3 \times 2 \times 94=564$

Tidak Baik (TB) $=2 \times 2 \times 94=376$

Sangat Tidak Baik (STB) $=1 \times 2 \times 94=188$



Hasil keseluruhan penilaian bahan ajar modul menggambar mode materi penyelesaian gambar desain busana dapat dilihat dari grafik dibawah ini: 
Grafik 4. 3 Hasil Persentase Penilaian Bahan Ajar Modul Menggambar Mode Materi Penyelesaian Gambar Desain Busana

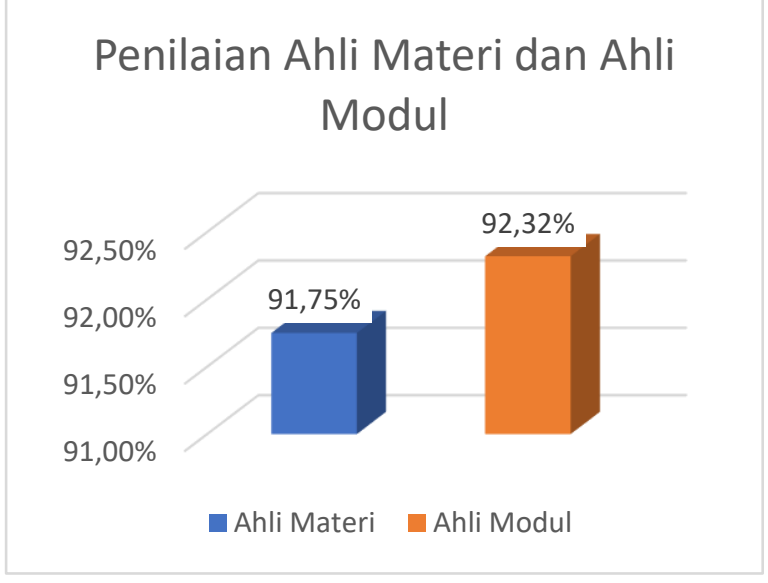

Berdasarkan hasil angket penilaian bahan ajar modul menurut ahli materi dan ahli media, didapatkan rata-rata sebesar $92 \%$ yang berarti bahwa modul dalam kategori Sangat Baik (SB) dari hasil yang diharapkan (100\%). Penilaian tertinggi diperoleh pada aspek Self Contained (Satu Kesatuan) dengan persentase sebesar 100\% dari hasil yang diharapkan (100\%). Penilaian terendah terdapat pada aspek Self Instructional (Pembelajaran Sendiri) dengan persentase sebesar $89,81 \%$ dari hasil yang diharapkan (100\%). Berdasarkan pemaparan dari keseluruhan hasil penelitian yang didapat sesuai dengan aspek bahan ajar yang baik menurut teori Abidin (2014) dan aspek karakteristik modul yang baik dan menarik menurut (Depdiknas, 2008). Maka modul dapat dikatakan sangat baik untuk digunakan sebagai bahan ajar modul materi penyelesaian gambar desain busana pada mata kuliah kejuruan busana.

\section{Pembahasan}

Penelitian ini ingin mengetahui penilaian bahan ajar modul menggambar mode materi penyelesaian gambar desain busana. Penilaian tersebut dilihat berdasarkan aspek bahan ahar dan karakteristik modul. Hasil penelitian ini menunjukan bahwa penilaian tertinggi diperoleh pada aspek self contained, hal tersebut sesuai dengan yang dikatakan Khoirunnisa et al., (2020) kedalaman materi dapat mengorganisasikan peserta didik untuk belajar. Aspek yang memperoleh nilai tertinggi kedua yaitu pada aspek user friendly, hal tersebut sesuai dengan Suliyanthini et al., (2021) modul juga mendukung pembelajaran individu dengan memungkinkan siswa untuk mereview atau meninjau kembali pelajaran yang diberikan di sebuah format. Aspek yang memperoleh nilai tertinggi ketiga yaitu pada aspek stand alone, hal tersebut sesuai dengan yang dikatakan Hafsah et al., (2016) keunggulan modul cetak karena tidak menggunakan alat bantu dalam penggunaanya. Aspek yang memperoleh nilai tertinggi keempat yaitu pada aspek penyajian, hal tersebut sesuai dengan yang dikatakan Romansyah (2016) Bahan ajar memiliki cakupan, kedalaman, serta urutan yang sistematis agar tercapainya tujuan pembelajaran. Aspek yang memperoleh nilai tertinggi kelima yaitu pada aspek kebahasaan, hal tersebut sesuai dengan yang dikatakan Sunarseh (2019) penggunaan bahasa yang tepat akan memudahkan pemahaman dalam belajar. Aspek yang memperoleh nilai tertinggi keenam yaitu pada aspek materi, hal tersebut sesuai dengan yang dikatakan Nugroho et al., (2019) menyatakan bahwa modul cetak yang baik yaitu modul yang menyajikan materi pembelajaran sesuai dengan kurikulum dan silabus. Aspek yang memperoleh nilai tertinggi ketujuh yaitu pada aspek adaptive, Hal tersebut sesuai dengan yang dikatakan Ibrahim (2010) dalam Nugroho et al., (2019) modul cetak yang baik dapat

42 |Practice of Fashion and Textile Education Journal; Vol 2, No 1. 
menyesuaikan dengan perkembangan teknologi, informasi dan komunikasi sehingga dapat tercapainya kompetensi dalam pembelajaran. Aspek yang memperoleh nilai tertinggi kedelapan yaitu pada aspek self instructional, hal tersebut sesuai dengan yang dikatakan Depdiknas (2006) modul dapat dipelajari peserta didik secara mandiri.

Kekurangan dalam modul ini yaitu materi yang disajikan terlalu singkat sehingga sebaiknya dapat ditambahkan materi yang lebih dalam lagi. Penggunaan kalimat pada langkah-langkah penyelesaian gambar desain busana sebaiknya dibuat lebih praktis dan tidak padat agar mudah dipahami peserta didik. Layout pada langkah-langkah penyelesaian gambar desain busana dibuat lebih menarik sehingga terlihat perbedaan antara pembahasan teori dan praktik.

Berdasarkan analisis diatas, maka bahan ajar modul menggambar mode materi penyelesaian gambar desain busana dapat dikatakan sangat baik karena telah sesuai dengan aspek bahan ajar dan karakteristik modul. hal ini sejalan dengan penelitian (Abidah, 2021) dimana penilaian bahan ajar modul sangat baik digunakan dalam pembelajaran yang dinilai berdasarkan aspek bahan ajar dan karakteristik modul. Penelitian ini juga sejalan dengan penelitian (Puspitasari, 2015) dimana pada penelitian ini sama-sama membahas tentang penyelesaian gambar busana.

Penggunaan bahan ajar modul menggambar mode materi penyelesaian gambar desain busana ini dapat digunakan sebagai alat bantu dalam kegiatan pembelajaran mata kuliah kejuruan busana, karena dalam bahan ajar modul menggambar mode materi penyelesaian gambar desain busana terdapat langkah-langkah pembuatan penyelesaian gambar desain busana dengan teknik pewarnaan secara kering dan basah.

\section{KESIMPULAN}

\section{b. Kesimpulan}

Sesuai dengan permasalahan dalam penelitian ini yang berfokuskan ingin mengetahui penilaian bahan ajar modul menggambar mode materi penyelesaian gambar desain busana berdasarkan aspek bahan ajar dan aspek karakteristik modul. Pembuatan modul ini melalui beberapa tahapan yang dimulai dari pengumpulan materi yang nantinya akan disusun dan sudah diidentifikasi berdasarkan rencana pembelajaran semester (RPS) dan sub capaian pembelajaran mata kuliah (CPMK). Setelah materi disusun sesuai dengan kerangka, kemudian dipilihlah bahan ajar berupa modul. Tahap selanjutnya yaitu proses tahapan pembuatan modul, yaitu pembuatan menggambar mode penyelesaian gambar desain busana, yang kemudian setiap tahapan dilakukan pengambilan gambar untuk dimasukan ke dalam modul. Setelah itu dilanjutkan dengan penyusunan materi beserta gambar/ilustrasi sesuai dengan konsep yang mendukung tampilan atau visualisasi bahan ajar modul menggunakan aplikasi online yaitu Canva.

Aspek bahan ajar yang harmonis, bermutu, dan bermartabat maka perlu memperhatikan beberapa aspek utama yaitu aspek materi, aspek penyajian, dan aspek kebahasaan. Sedangkan aspek karakteristik modul yang baik dan menarik yaitu apabila terdapat self instructional, self contained, stand alone, adaptive, dan user friendly. Hasil data penilaian pada penelitian ini aspek yang paling dominan dan mempengaruhi penilaian bahan ajar modul menggambar mode materi penyelesaian gambar desain busana yaitu aspek self contained hal ini dikarenakan dalam aspek self contained di dalam modul terdapat kompetensi dan sub kompetensi secara utuh dan tuntas, sehingga peserta didik dapat mempelajari materi secara utuh hanya dalam satu modul. Berdasarkan hasil analisis data penelitian, maka dapat disimpulkan bahwa bahan ajar modul menggambar mode materi 
penyelesaian gambar desain busana ini sudah dinyatakan sangat baik untuk digunakan, karena telah sesuai dengan bahan ajar yang baik dan karakteristik modul yang baik. Sehingga bahan ajar modul yang telah dibuat oleh peneliti dapat digunakan sebagai bahan ajar modul materi penyelesaian gambar desain busana pada mata kuliah kejuruan busana.

\section{c. Implikasi}

Bahan ajar modul menggambar mode materi penyelesaian gambar desain busana dapat digunakan sebagai pendamping atau alat bantu bagi Dosen dalam menyampaikan materi pembelajaran penyelesaian gambar desain busana dalam mata kuliah menggambar mode dan referensi sumber bacaan bagi mahasiswa. Modul ini diharapkan dapat menjadi sebuah acuan bagi Dosen Program Studi Pendidikan Tata Busana untuk mengembangkan dan menggunakan bahan ajar untuk menunjang kegiatan pembelajaran. Selanjutnya dalam melihat hasil penilaian bahan ajar modul mungkin dapat diterapkan pada media pembelajaran lainnya, seperti video tutorial maupun e-modul.

\section{d. Saran}

Berdasarkan hasil penelitian tentang penilaian bahan ajar modul menggambar mode materi penyelesaian gambar desain busana, maka peneliti memberikan saran pemanfaatan modul sebagai berikut:

1. Bagi Mahasiswa

Mahasiswa sebaiknya lebih mandiri dalam proses pembelajaran dan aktif memanfaatkan bahan ajar modul dalam upaya meningkatkan kemampuan penyelesaian gambar desain busana. Modul menggambar mode materi penyelesaian gambar desain busana dapat dijadikan referensi untuk penelitian dan mahasiswa diharapkan dapat mengembangkan produk bahan ajar modul,

2. Bagi Dosen Pengampu Mata Kuliah

Hasil penilaian bahan ajar modul menggambar mode materi penyelesaian gambar desain busana ini dapat digunakan sebagai alat bantu dalam proses kegiatan belajar dan mengajar.

\section{E. DAFTAR PUSTAKA}

Abidin, Y. (2014a). Desain Sistem Pembelajaran Dalam Konteks Kurikulum 2013 (aep gunarsa (ed.)). PT Refrika Aditama.

Bestari, A. G. (2011). Menggambar Busana Dengan Teknik Kering (L. S. Fiki Puspitasari (ed.); pertama). KTSP.

Daryanto, (2013). Inovasi Pembelajaran Efektif. Bandung: Yrma Widya.

Depdiknas, B. S. N. (2006). Kurikulum Tingkat Satuan Pendidikan. Jakarta: Departemen Pendidikan Nasional, 9-27.

Departemen Pendidikan Nasional, 9-27.

Depdiknas, B. S. N. (2008). Penulisan Modul. Jakarta: Departemen Pendidikan Nasional.

Hasanah, Uswatun, M. P. dan M. N. (2011). Menggambar Busana (Adriyani Kamsyach (ed.)). PT Remaja Rosdakarya.

Muchamad Noerharyono (2021) Rencana Pembeljaran Semester Menggambar Mode. Universitas Negeri Jakarta.

Muliawan, P. (2002). Menggambar Mode Dan Mencipta Busana Wanita (pertama). PT BPK Gunung Mulia.

Nasution, Afrianto, Nurfadillah Salam, S. \& J., Nim, N., Sadjati, I. M., Agent, S. G., Sifat, T., Dan, F., Studi, P., Pangan, T., Pertanian, F. T., Katolik, U., Mandala, W., \& Aceh, D. (2017). Berbagai Pendekatan dalam Proses Belajar dan Mengajar. Pendidikam, 3(1), 1-62. 
https://doi.org/10.1017/CBO9781107415324.004

Prastowo, A. (2014b). Panduan Kreatif Membuat Bahan Ajar Inovatif (D. Wijaya (ed.); VI). DIVA Press.

Saebani, B. A. dan Y. S. (2018). Metode Penelitian (Tim Redaksi Pustaka Setia (ed.); 1st ed.). CV Pustaka Setia.

Siyoto, S. dan A. S. (2015). Dasar Metodologi Penelitian (Pertama). Literasi Media Publishing. Sugiyono. (2015). Metode Penelitian Pendidikan (Pendekatan Kuantitatif, Kualitatif, dan $R \& D)$. Alfabeta,CV.

Sumber Jurnal:

Aditia, M. Taufik \& Muspiroh, N. (2013). Pengembangan Modul Pembelajaran Berbasis Sains, Lingkungan, Teknologi, Masyarakat Dan Islam (Salingtemasis) Dalam Meningkatkan Hasil Belajar Siswa Pada Konsep Ekosistem Kelas X Di Sma Nu (Nadhatul Ulama) Lemahabang Kabupaten Cirebon. Scienticiae Educatia, 2(2), 8-9.

Hafsah, N. R., Rohendi, D., \& Purnawan, P. (2016). Penerapan Media Pembelajaran Modul Elektronik Untuk Meningkatkan Hasil Belajar Siswa Pada Mata Pelajaran Teknologi Mekanik. Journal of Mechanical Engineering Education, 3(1), 106. https://doi.org/10.17509/jmee.v3i1.3200

Harta, I., Tenggara, S., \& Kartasura, P. (2014). Pengembangan Modul Pembelajaran untuk Meningkatkan Pemahaman Konsep dan Minat SMP. Pythagoras: Jurnal Pendidikan Matematika, 9(2), 161-174. https://doi.org/10.21831/pg.v9i2.9077

Izzati, N., \& Fatikhah, I. (2015). Pengembangan Modul Pembelajaran Matematika Bermuatan Emotion Quotient Pada Pokok Bahasan Himpunan. Eduma: Mathematics Education Learning and Teaching, 4(2). https://doi.org/10.24235/eduma.v4i2.29

Junaedi, I. (2019). Proses pembelajaran yang efektif. Journal of Information System, Applied, Management, Accounting and Research, 3(2), 19-25.

Magdalena, I., Sundari, T., Nurkamilah, S., Nasrullah, \& Amalia, D. A. (2020). Analisis Bahan Ajar. Nusantara : Jurnal Pendidikan Dan Ilmu Sosial, 2(2), 311-326.

Muliawani, \& Firma Firman. (2019). Bahan Ajar Pembelajaran Tematik Terpadu Berbasis Model Problem Based Learning (PBL) Sekolah Dasar. https://www.researchgate.net/publication/330162412

Nugroho, Y. S., Suyitno, S., Daryanto, D., Achmad, F., Ningrum, L. E. C., \& Rohman, M. (2019). Pengembangan Modul Pembelajaran Mata Kuliah Energi Alternatif Program Studi Pendidikan Vokasional Teknik Elektro. JINoP (Jurnal Inovasi Pembelajaran), 5(1), 93. https://doi.org/10.22219/jinop.v5i1.8923

Rahdiyanta. (2016). Teknik Penyusunan Modul. Artikel.(Online) http://staff. uny. ac. $\mathrm{id} /$ sites/default/files/penelitian/dr-dwi-rahdiyanta-mpd/20-teknik-penyusunan-modul. pdf. diakses

S.Sirate, S. F., \& Ramadhana, R. (2017). Pengembangan Modul Pembelajaran Berbasis $\begin{array}{llll}\text { Keterampilan Literasi. Inspiratif } & \text { Pendidikan, }\end{array}$ https://doi.org/10.24252/ip.v6i2.5763

Salaka, J. (2020). No Title. 2, 62-65.

Suliyanthini, D., Yulianur, F., Zahra, E. L., Radiona, V., \& Lubis, H. (2021). Student cognitive level achievement in the textile chemistry lesson conducted in a blended learning environment. AIP Conference Proceedings, 2331(April). https://doi.org/10.1063/5.0041792

Sunarseh, Daningsih, E., \& Marlina, R. (2019). Kelayakan Modul Submateri Struktur dan Fungsi 
Jaringan Tumbuhan XI SMA Berdasarkan Jumlah dan Ukuran Stomata Monokotil. Jurnal Pendidikan Dan Pembelajaran Khatulistiwa, 8(6), 1-11.

Utami, D. A. (2020). Pengembangan Bahan Ajar Berbasis Modul Interaktif Bagi Pemelejar BIPA Tingkat A1. KREDO: Jurnal Ilmiah Bahasa Dan Sastra, 3(2), 277-294. https://doi.org/10.24176/kredo.v3i2.4747

Sumber Web:

https://www.alvarium.id/berikut-adalah-fungsi-dan-cara-penggunaan-dari-spidol-crayondan-pensil-warna

https://www.fesyendesign.com/teknik-penyajian-desain-busana/ 